University of Chicago Law School

Chicago Unbound

Journal Articles

Faculty Scholarship

1995

\title{
Gomorrah to Ybarra and More: Overextraction and the Puzzle of Immoderate Group Liability
}

Saul Levmore

Follow this and additional works at: https://chicagounbound.uchicago.edu/journal_articles

Part of the Law Commons

\section{Recommended Citation}

Saul Levmore, "Gomorrah to Ybarra and More: Overextraction and the Puzzle of Immoderate Group Liability," 81 Virginia Law Review 1561 (1995).

This Article is brought to you for free and open access by the Faculty Scholarship at Chicago Unbound. It has been accepted for inclusion in Journal Articles by an authorized administrator of Chicago Unbound. For more information, please contact unbound@law.uchicago.edu. 


\section{VIRGINIA LAW REVIEW}

\begin{tabular}{lll}
\hline \hline Volume 81 & September 1995 & Number 6 \\
\hline \hline
\end{tabular}

ARTICLE

GOMORRAH TO YBARRA AND MORE:

OVEREXTRACTION AND THE PUZZLE OF

IMMODERATE GROUP LIABILITY

Saul Levmore*

\section{INTRODUCTION}

TMAGINE that you are jostled in an office building elevator and you sense that your wallet, with $\$ 100$ in it, has been taken. There are five fellow passengers in the elevator, and as the door opens a police officer stands before you. The officer is sympathetic to your problein, but is unable to narrow the group of suspects in order to carry out a search. None of the five suspects volunteers to be searched. There is the possibility that the victim could be made whole by a recovery of twenty dollars from each of the five suspects. ${ }^{1}$ We might think of such liability as a form of communal responsibility, familiar since the Biblical story of Sodom and Gomorrah, ${ }^{2}$ where this kind of remedy, affecting the innocent along with the culpable, lias been described by soine commentators

* Brokaw Professor of Corporate Law and Albert Clark Tate, Jr. Professor, University of Virginia. I am grateful for comments received from Clay Gillette, Jim Lindgren, Thomas Sachson, Robert Scott, Bill Stuntz, Rip Verkerke, and participants at faculty workshops at the University of Virginia and Chicago-Kent Law Schools.

1 The analysis is facilitated by the assumption of facts that make us certain that the victim lost $\$ 100$ to a pickpocket. We might imagine that immediately prior to boarding, the victim purchased a newspaper, and witnesses report the victim's receipt of change from a $\$ 100$ bill.

2 Genesis 18:22-19:29. 
as reflecting the responsibility of the community for the wrongdoing within it. ${ }^{3}$ A modern, perhaps more functional, justification for this kind of joint liability is that it might encourage otherwise silent witnesses to help identify the chief culprit who would then bear the entire liability (and perhaps criminal punishment as well).

This kind of "information forcing" rule, or explanation for a rule, inay have peaked with medieval frankpledging, whereby small groups of (at least ten) individuals forfeited their bonds or deposits when one of their number escaped arrest for a crime. ${ }^{4}$ Yet it is surprisingly similar to the famous case of Ybarra v. Spangard, ${ }^{5}$ where a patient was able to recover from a number of health professionals for an injury sustamed during an operation. The facts suggested that one (unidentified) defendant negligently caused the imjury, and the decision can be read as hinting that a plaintiff should not go uncompensated simply because doctors and nurses may be unlikely to testify against one another and identify the wrongdoer. ${ }^{6}$ Ybarra is not a startling case, although it represents a

3 See David Daube, Two Notes on Communal Responsibility, 36 Soc. Rev. 24 (1944) (describing Abraham as reacting to communal responsibility, or the idea that a community is tainted and punished for the crime of a member, with the suggestion of communal merit, whereby a community might be saved on account of at least a number of righteous inhabitants, and contrasting these with ruler responsibility, under which a community suffers as the property of a guilty ruler). Even the first description in the text may have too much of a functional ring to it, because the ancient taint may have nothing to do with "responsibility" in the sense of ability to monitor and to correct. There are, however, other ancient references that reflect a kind of responsibility or even vicarious liability. See Saul Levmore, Rethinking Group Responsibility and Strategic Threats in Biblical Texts and Modern Law, 70 Chi.-Kent L. Rev. (forthcoming 1995) (on file with the Virginia Law Review Association). In any event, a plausible reading of the Sodom and Gomorrah story is not that Abraham bargained down the degree of communal responsibility, but rather that there were simply no good people to be found in the doomed cities. And even if the story does assume communal responsibility, it is hardly the case that many suffered for the deeds of a few, but rather that a few may have suffered for the deeds of the many. For these reasons I proffer this story not as the best example ancient law has to offer but rather as a famous (possible) example and as a convenient way of referring to Professor Daube's interesting article.

4 See William Alfred Morris, The Frankpledge System (1910).

5154 P.2d 687 (Cal. 1944).

6 Id. at 689 (stating that the "patient ... would be entirely unable to recover unless the doctors and nurses in attendance voluntarily chose to disclose the identity of the negligent person"); see also Dierman v. Providence Hosp., 188 P.2d 12, 13-15 (Cal. 1947) (using res ipsa loquitur in plaintiff's favor, apparently influenced by a nurse's vague testimony and by the failure of defendants to produce evidence in their control which might have resolved uncertainty regarding cause of injury). 
minority view, and yet there is something startling about applying its principles to force passengers in an elevator to compensate a pickpocket victim. ${ }^{7}$ We sense that these passengers will not, and should not, be held liable. One goal of this Article is to understand the limits of Ybarra and the occasional attraction of placing calculated burdens on the imiocent and culpable alike.

If Ybarra is an example of shrewd, judge-made law because of its information-forcing potential, ${ }^{8}$ then a more clever rule would not only encourage witnesses but also persuade the wrongdoer to confess or to right the wrong. If the Ybarra-style rule calls for each of the five suspects to pay twenty dollars, then we might contemplate a radical rule requiring all six passengers to pay more than $\$ 100$ each, perhaps $\$ 150$, into the hands of a police officer or other third party. ${ }^{9}$ This stakeholder would return all funds if the stolen wallet and money are immediately returned, but otherwise would give it all to a charity or to the government, where it might be earmarked for crime-fighting or prison construction. The scheme would only be used when there appeared to be no other means of identifying the wrongdoer and imposing criminal or tort penalties. The idea is to make the thief an offer that will not be refused. If the thief keeps the wallet, the thief loses the $\$ 150$ "overextracted" by this iminoderate group liability rule; ${ }^{10}$ if the thief returns the wallet,

7 See infra Part I.A. I think it fair to say that Ybarra is even well regarded in the sense that if it should turn out to force information most of the time, then most observers would regard it as a good decision. Alternatively, Ybarra may be regarded or even applauded as simply balancing the "conspiracy of silence" among professionals, see W. Page Keeton, Dan B. Dobbs, Robert E. Keeton \& David G. Owen, Prosser and Keeton on the Law of Torts $\$ 39$, at 253 (5th ed. 1984) [hereinafter Prosser and Keeton], even if there is no expectation that the threat of liability will bring out information. This latter view of the "group liability" in Ybarra does not impede the analysis in the text, but it makes Ybarra less like the overextractive rule presently described.

8 The idea, once again, is that liability may help overcome the disinclination of health professionals to testify against one another.

9 The rule in the text includes the victim as one of the passengers required to contribute. Part II discusses the amount of the victim's payment (and other details of the scheme).

10 I use the term "group liability" to refer to liability that falls on a group which includes some blameless members. Communal responsibility is the traditional expression for this sort of remedy or punishment, but communal responsibility is usually thought of as applying to a large group such as a tribe or city. The group liability referred to in this Article is usually a kind of "joint liability," but I try to use group liability as a subset of joint liability. Finally, the expression "Ybarra-style liability" is synonymous with group liability, although the discussion in Part I.B emphasizes that Ybarra is in fact but one relatively small source or subset of such liability. 
then the thief enjoys the $\$ 150$ returned from the stakeholder. The rational thief will presumably return what has been stolen, spending $\$ 100$ to inake $\$ 150$. When the thief responds "rationally," all passengers receive their inoney back. Thus, the success, and perhaps even the popularity, of this "overextraction rule" depends rather plainly on the empirical question of how often pickpockets will return wallets and how much crime will be deterred in the first place once potential wrongdoers know that the rule will preclude gainful theft.

There are obvious (and subtle) mechanical and conceptual problems with this overextraction idea, and the discussion in Part II explores these problems and the details that must be incorporated into a successful overextraction scheme. I advance the overextraction idea as a thought experiment, both because virtually all readers will (at least at the outset) abhor this overextractive rule and because what is most interesting about it is not the promise of its sensible application (which is probably limited), but the puzzling lack of experimentation with such a rule and the inplications for inore inodest group liability that flow from it. ${ }^{11}$ Even where "group liability" is likely to be popular, as in charging a number of businesses for the costs associated with cleaning up a polluted site, there is no thought of imposing overextractive charges in order to elicit rational confessions froin wrongful polluters. I hope to show that we can learn about law by asking why the overextraction idea (such as demanding $\$ 150$ froin each passenger in the elevator) is not used to resolve uncertainty and to deter wrongdoing.

Part I begins with the scope of group hability in contemporary law. I aim to show that there is inuch more Ybarra-like liability in law than flrst meets the eye. Part II returns to the overextraction alternative introduced above. I emphasize that many of the probleins that can be associated with overextraction are also found where Ybarra-like joint liability is used. The absence of overex-

11 I have also explored the use of group liability in ancient, and especially in Biblical, law. Generally speaking, ancient and medieval lawmakers are reported to have been much less reserved than modern legal systems about employing group liability, even though the innocent suffered along with the guilty. Nevertheless, even in these older legal systems, there are virtually no obvious examples of the extension of such liability or punishment to the overextraction point where the rational wrongdoer will confess. In subtle forms, overextraction might be found in the story of Jonall and elsewhere. See Levmore, supra note 2. 
tractive liability is therefore somewhat puzzling because it has many advantages over more modest group liability. Part III concentrates on the questions of wliy the overextraction idea is unattractive, or at least untried, and why the more modest Ybarra rule has spread only in certam directions. I suggest that the development of overextraction remedies may have been arrested by antipathy toward uninsurable risks and fears of destructive threats and that to explam the absence of overextraction rules may also be to understand the scope of (Ybarra-like) group liability in law.

\section{Group Liability in Contemporary LaW}

\section{A. The Doctrinal Limits of Ybarra}

Ybarra $v$. Spangard itself is of uncertain precedential value. A number of courts have explicitly rejected its holding even in virtually identical medical malpractice settings. ${ }^{12}$ Other courts have adopted or followed Ybarra but, by focusing on the need for liability to overcome the "shroud of silence" among health providers, suggested that the rule may be limited to medical malpractice cases. ${ }^{13}$ An information-forcing rule may also be regarded as especially productive in the medical setting because potential defendants do or could monitor one another. Alternatively, medical patients might be seen as having a special, if implicit, contract or relationship with those who provide medical treatment.

If Ybarra is confined to hospital settings, it is of limited precedential importance because in such situations it will often be the case that the plaintiff can sue the hospital and through vicarious liability overcome the defense that the identity of the actual wrongdoer is unknown. If the hospital is vicariously liable for all its employees, then the plaintiff will win when it is clear that an imjury

12 See, e.g., Barrett v. Emanuel Hosp., 669 P.2d 835 (Or. Ct. App. 1983) (rejecting idea that anything can be inferred from mere occurrence of injury); Talbot v. Dr. W.H. Groves' Latter-Day Saints Hosp., Inc., 440 P.2d 872 (Utah 1968) (holding that numbness in arm following operation does not establish sufficient causation to reach defendants because nonnegligent causes also possible).

Although it is conventional wisdom, and probably sensibly so, to view Ybarra as less than universally followed, it is noteworthy that cases just like it do not seem to arise very often. In Barrett, for example, although the court never mentions the possibility that plaintiff's injury is questionable, the complaint, alleging mental and nervous disorders arising out of a knee operation, is likely to arouse suspicion.

13 See, e.g., Van Zee v. Sioux Valley Hosp., 315 N.W.2d 489, 494 (S.D. 1982). 
was caused by some employee in the operating room and that all present in the operating room, aside from the patient, were hospital employees. Indeed, in Ybarra itself, where some of the "suspects" were not employees of the hospital, the court implied that it would be prepared to hold that these non-employees were nevertheless agents of the surgeon, so that vicarious liability would solve the plaintiff's doctrinal difficulty. ${ }^{14}$ In any event, even if Ybarra is limited only by the contract or special relationship idea, that would be enough to keep it from spreading to our elevator passengers and to many other settings where an information-forcing rule might be useful.

In NOPCO Chemical Division v. Blaw-Knox Co. ${ }^{15}$ the plaintiff took delivery of a damaged machme that had been handled by three unrelated parties after it left the manufacturer's control. The plaintiff had hired one of these parties to transport the machine from its manufacturer to a storage facility owned by a second party, where it would remain until the plaintiff's factory was readied for the new equipment. The third party was chosen by the plaintiff to transport the machine from this storage facihty to the plaintiff's factory floor. The machine was somewhere damaged by the negligent operation of a forklift. The defect was sufficiently hidden by protective coverings so that no one would have seen the problem when receiving the machine from the previous handler. The New Jersey Supreme Court decided the case in the plaintiff's favor, declaring that it was unfair to burden the plaintiff with the nearly impossible task of proving who damaged the machine. ${ }^{16}$

NOPCO would seem to outflank Ybarra, because the NOPCO defendants were less likely than those in Ybarra to have information about one another's behavior; there was no implicit contract with the group of defendants; there was no particular reason to fear a "conspiracy of silence" among defendants; and there was not even the possibility (as there was in Ybarra) of judicial sympathy for a plaintiff whose claim of vicarious liability might normally have succeeded. NOPCO's imposition of group liability, despite the plaintiff's inability to satisfy the usual preponderance-of-the-

14 Ybarra, 154 P.2d at 690.

15281 A.2d 793 (N.J. 1971).

16 Id. at 797. 
evidence standard against any defendant, might be defended as serving to ehicit exculpatory evidence from a given defendant about its own behavior, even if it could not be expected to force out information about the behavior of fellow defendants. Put differently, if im Ybarra the defendants had not all been in the operating theater at once but rather had come and gone from the plaintiff's bedside one at a time, liability would have been much less likely. And NOPCO is at best a nonmedical version of just such a variant of Ybarra, and at worst (for future defendants) very different because in NOPCO there is no sense in which liability might "really" be of the vicarious kind. The doctors and nurses in Ybarra may all have been working for the hospital (in fact if not in law), but the defendants in NOPCO were individually selected by the plaintiff and had no ongoing contractual relationship with one another.

Unsurprisingly, NOPCO is rarely cited ${ }^{17}$ and is one of the few judicial decisions to go beyond Ybarra in imposing group habihty. More representative is Samson v. Riesing, ${ }^{18}$ where responsibility for salmonella poisoning was not placed. on the eleven defendants who had all prepared turkeys or worked on the turkey salad for a school picnic. At least one of the defendants was probably negligent, but there was little chance that the threat of hability would have forced out useful information; nor were the defendants related in a way that would have warranted bending the requirements for vicarious liability. ${ }^{19}$ I suspect that even the New Jersey Supreme Court would have resisted imposing liability in NOPCO

17 Three other cases governed by New Jersey law cite NOPCO: Raritan Trucking Corp. v. Aero Commander, Inc., 458 F.2d 1106 (3d Cir. 1972) (agreeing that language in NOPCO suggests that its holding could be limited to situations involving a bailee for purposes of transportation); Shackil v. Lederle Lab., 561 A.2d 511 (N.J. 1989) (refusing to impose NOPCO group liability based on market share for injuries arising out of vaccinations); and Anderson v. Somberg, 338 A.2d 1 (N.J. 1975) (placing actual burden of proof on defendant medical team, hospital and manufacturer of forceps).

18215 N.W.2d 662 (Wis. 1974).

19 Put differently, the common interest of these defendants could provide a source of vicarious or other liability, but schools, clubs and other organizations would become insurers and would pass along premium costs contrary to popular preferences. See infra text accompanying notes 71-75 (linking Ybarra-style liability to the presence of businesses rather than unirssured individuals). 
had the wrongdoer been hidden in a group of ten rather than two innocent people. ${ }^{20}$

\section{B. The Real Scope of Ybarra}

There is, however, much more group liability than first meets the eye when the identity of the wrongdoer is uncertain. I have already alluded to the first reason for this conclusion by implying that Ybarra may be of limited precedential importance because in so many like cases the plaintiff will succeed with a claim based on vicarious liability, even though it is impossible to identify the wrongdoing agent. ${ }^{21}$ Put simply, the doctrine of vicarious liability often places liability on an innocent member of a "group."

Products liability law is perhaps the most inportant reason for my description of the real scope of Ybarra. If an automobile

20 Indeed, the other cases that expand upon Ybarra involve just two or three defendants so that the "error costs" of shifting the burden of proof are low. Compare Jackson v. Magnavox Corp., 280 A.2d 692 (N.J. Super. Ct. App. Div. 1971) (emphasizing that uncertainty as to liability is narrowed to two defendants) and Litzmann v. Humboldt County, 273 P.2d 82 (Cal. Dist. Ct. App. 1954) (refusing to exonerate two possible wrongdoers because of uncertainty in action against the alleged wrongdoers and the county which sponsored the fair at which explosion took place) with Clift v. Nelson, 608 P.2d 647 (Wash. Ct. App. 1980) (denying action against crowd of onlookers absent particularized showing of personal culpability).

21 The philosophical link between group liability and vicarious liability is noted in Robert A. Baruch Bush, Between Two Worlds: The Shift from Individual to Group Responsibility in the Law of Causation of Injury, 33 UCLA L. Rev. 1473, 1477 (1986) (arguing that vicarious liability, absent negligent supervision, clashes with notions of individual responsibility).

One practical link between vicarious and group liability is that courts can find that one defendant was the agent of another. Compare NOPCO Chemical Div. v. Blaw-Knox Co., 281 A.2d 793 (N.J. 1971), where the plaintiff chose to deal with each of the defendants, with General Electric Co. v. Pennsylvania R.R., 160 F.Supp. 186 (W.D. Pa. 1958), where damage to transported refrigerators could have been caused by any of three defendants (or even two unnamed carriers), and the court was content to let the nanied defendants exonerate themselves or implicate one another. The facts suggest that each carrier might have chosen the next, and there is therefore the likelihood that the court thought of the defendants in principal-agent terms. Another case along these lines may be Jackson v. Magnavox Corp., 280 A.2d 692 (N.J. Super. Ct. App. Div. 1971), where the plaintiffs were injured when their car ran into a negligently parked trailer. Magnavox, which had goods to be hauled, was to have returned the trailer to a second defendant, Merit, which had done the hauling. It was unclear whether the trailer had been returned to Merit before the accident, but it was certainly not in the control of a third defendant, a railroad, which had the general lease on the trailer. The jury was told to find against Magnavox or Merit. Again, these defendants might be seen as participating in an agency relationship. 
explodes, a victim may collect from the manufacturer of this apparently defective product without pointing to the precise component (and therefore subcontractor) of that product that was negligently made and that caused the explosion. Products liability law looks to the least-cost avoider-wliere that expression refers not only to direct precautions but also to tlie ability to contract with other precaution takers. Indeed, once we recollect that the historical, doctrinal obstacle in the way of products liability was lack of privity between consumer and manufacturer, it is easy to see that in the absence of that obstacle vicarious liability and products liability are close relatives. 22

I am suggesting that in many cases where there is uncertainty about the identity of the wrongdoer, or at least where this uncertainty can be reduced to the point where there is a mere handful of suspects (some of wliom may be nonculpable so that the uncertainty is not simply about whiclt of a number of wrongdoers caused the injury in question), vicarious liability or products liability doctrine permits recovery, and often serves to spread the costs of the loss across the "community" or target group in which the actual wrongdoer is most narrowly found. This is precisely what Ybarra did im the operating room, but that case was difficult only because it did not involve a product and, apparently, because tlie formal hierarchy necessary to trigger vicarious liability was absent. Potential plaimtiffs, whicl is to say all citizens who do not know whether the negligence that may one day cause them some injury will come from a defective product or from a group of doctors (wlio may or may not work for one another or for a common hospital), ought to regard Ybarra as a relatively small part of the law's nonumversal willingness to find liability where the actual wrongdoer is unidentified. Vicarious liability and products liability are far more important developments in this regard. Put differently, if we opted for Ybarra-style liability in our elevator case, so that eacli passenger

22 This comparison suggests that the exception in vicarious liability law for independent contractors is somewhat puzzling because this is, in a sense, the precise relationship of the maker of a component part to the manufacturer of the automobile. In any event, both vicarious and products liability can raise prices among suppliers and otherwise lead to cost sharing in the manner of Ybarra. In turn, indemnification agreements can refocus the burden of liability but this is also the case in Ybarra, where indemnification agreements, like. insurance contracts, are presumably enforceable. 
paid twenty dollars to the victim, the case would still be of relatively himited impact because so many cases of comparable uncertainty are already decided in the plaintiffs' favor as a result of vicarious liability and products hability law.

There is also a more dramatic and less doctrinally driven reason to think that group responsibility, as in Ybarra, is commonly the de facto rule when the identity of the (causal agent and) wrongdoer is uncertain. ${ }^{23}$ When victims are repeat players, they will generally be able to share losses with other innocent players and perhaps with a group that includes both innocents and unidentifiable wrongdoers. Thus, shoplifting raises prices in a way that forces all shoppers (including most shoplifters, who are likely to acquire some of their goods through normal purchases) to bear the cost of this crime; tax fraud probably imposes costs on all citizens and surely on all taxpayers; and unsolved burglaries and many other crimes impose costs on all property owners. The costs of some crimes and torts are borne inore broadly than others but the point is that $\mathrm{m}$ the long run the cost of undeterred wrongdoing is shared by many innocent people through higher prices and taxes, the costs of taking precautions, and the hidden costs of avoiding certain activities or locations.

In the case of the pickpocket on the elevator, there is less potential for loss sharing because there is little repeat playing. Once the wrongdoer has struck, passengers are unlikely to agree to share the loss (much less agree to a less moderate group liability rule) even though some of these passengers might have agreed on such a scheme ex ante, before they knew who among them would become the victim. To the extent that many passengers would agree ex ante to an Ybarra rule or more, there is of course the familiar argument for imposing (legislatively or judicially) that which citizens would bargain for in the absence of transaction costs. Some measure of group responsibility may satisfy this criterion.

If most passengers would in fact decline an ex ante opportunity to opt in to an Ybarra-style rule, they might do so because of a kind of confidence or fear of the moral hazard that some of their

23 Broad and formal (as opposed to de facto) community responsibility is not unknown. The most serious examples of group liability involve wars fought because of the behavior or interests of a part of the population. For a discussion of this aspect of group liability, see Levmore, supra note 2. 
fellow passengers are more likely, or will now be more likely, to fall prey to the pickpocket tlian they. ${ }^{24}$ It is no accident that more people purchase insurance covering the theft of their automobiles, for example, than purchase traveler's checks or other forms of pickpocket insurance. Even in a world without insurance many people might decline to share losses more than they must, but the point is that a great deal of sharing will occur naturally. In its simplest form, this sharing comes from repeat playing, so that the elevator case inay be unusual because it is a scenario that is not often repeated with the saine passengers. If it were repeated, it would make little difference whether the apparent rule was no liability or Ybarra, or whetler passengers agreed ex post or ex ante or even through insurance contracts to share in the losses. In the long run, given the pervasiveness and costs of crime, group liability is the de facto rule for people who work or live near one another.

The same is true of many torts. If we are unable to identify the polluter of a waterway, we might eventually resort to a tax on, or to assigning cleanup costs to, nearby factories, or to an industry as a whole. When these costs are borne by taxpayers, recreational users, or consumers of fish, it is apparent that innocent people are forced to pay for the wrongs the law could not or chose not to assign. As the target group is narrowed, the private incentive to help identify the wrongdoer increases, yet even in the absence of identification, greater liability falls on the actual wrongdoer. At the same time, however, more imnocents are made to pay in a way that may seem both distributionally unfair and likely to generate inefficient activity-level effects as these innocents try to keep their distance from liability.

Majoritarian tastes and power generate "natural" group hability. Soine people inay not agree to group responsibility as they enter the elevator, but most people (or their elected representatives) will

24 Some people may guard their valuables less jealously than others. And some people carry around a great deal more money and jewelry than others. Most insurance schemes require larger premiums for larger risks. One might try a scheme such as that represented by general average contribution in admiralty law, in which all passengers on the elevator contributed according to the value of what they brought onto the elevator, but it would be impossible to carry out this plan without searching all the passengers, and uncertainty would be inevitable because such searches cannot be required. In other settings it would simply be difficult to combine the principles of general average contribution and overextraction. 
agree to some sharing of this kind when faced with certain social problems caused by wrongdoers who are difficult to identify. At one level there are rules that resolve uncertainty by imposing hability on industries and subsets of citizens. Environmental cleanup charges and minimum driving and drinking age laws are examples of these broadly imposed costs. But at a less refined level there is almost no end to the list of measures that can at least in part be described as spreading costs in the manner of Ybarra. Many taxes, affirmative action plans, curfews and reporting requirements can be viewed in this way. In all these cases we might well choose to impose liability on known wrongdoers if we could do so costlessly; it is $\mathrm{m}$ the face of uncertainty that we share burdens more widely for reasons of deterrence or compensation or both. ${ }^{25}$ If Ybarra is about providing some deterrence (even if only at the activity level), some insurance, and some incentive to report wrongdoing by others, then an enormous amount of government regulation can be described as of a piece with Ybarra. If there was something remarkable about the decision in Ybarra, perhaps it was simply the fact of its judicial rather than legislative origins.

If the scope of group liability is accepted as quite great, and Ybarra as just one small piece of this reality, then the question becomes not so much why and when we employ group responsibility, but rather why and when we do not always refine such liability by even more regularly imposing it on well-defined narrow target groups. One answer appears to be that we sliy away from such "refined" group liability when the narrow target group lacks the contractual links that may normally be a proxy for repeat playing. Although NOPCO remains the doctrimal outlier, it is perhaps more defensible under this view than any other because the plaintiff is contractually linked to the defendants, even though there is no repeat playing.

A second factor in deciding between Ybarra (or vicarious liability or products liabihty) and broader group liability (through taxes, price increases, and other nonjudicial means) builds on an important difference between refined and de facto group hability. Both

25 These goals normally lead to some narrowing of the target group. Thus, curfews are sometimes imposed on those under a specified age. And in taxing cigarettes and alcohol, we may be pleased if one effect is reduced consumption (and therefore reduced external effects). 
types of group liability impose costs on innocent players, but only refined, case-oriented liability offers compensation to (uninsured) victims. A plaintiff who cannot point precisely to the wrongdoer who caused his mjury may be compensated through products liability law, vicarious liability law, or occasional decisions sucl as Ybarra and NOPCO. But when the claim falls into none of these categories, the fact that there may be ultimate loss sharing because of taxation scheines or simply through repeat playmg does little for the victim in a given case. The point is not to extol the advantages of refined group liability, but rather to illuminate the line between refined and de facto group liability by observing that without compensation there is no incentive to report losses dishonestly. ${ }^{26}$ The court in Ybarra seemed certain that the injury was inflicted in the operating room, ${ }^{27}$ and the NOPCO court emphasized that the plaintiff could not have damaged the equipment in question. ${ }^{28}$ But in many cases there will be reason to fear false claims if group liability provides compensation. ${ }^{29}$ In a sense, this explanation is but one step removed from the question of why we do not regularly use rewards (rather than the threat of Ybarra liability, for example) to encourage witnesses. ${ }^{30}$

Finally, a third explanation for the apparent preference either for no liability or for broad (and moderate) group liability over refined, Ybarra-style liability relates to risk aversion, or the taste

26 If there are insurance schemes in place, there will of course be compensation and similar incentives to manufacture claims. But first-party insurance will control some false claims through deductibles and experience ratings.

27 Ybarra, 154 P.2d at 689-90 (suggesting that the patient was at all relevant times in the exclusive control of the defendants).

28 NOPCO, 281 A.2d at $795-96$ (stating that source of damage discovered by manufacturer's field engineer and plaintiff established that the damage most likely occurred in transit).

29 The discussion in Part III.C extends this argument in considering the likelihood of false accusations.

30 The moral hazard associated with rewards relates to the danger that reward-seekers will help create losses that, in turn, stimulate rewards. Saul Levmore, Waiting for Rescue: An Essay on the Evolution and Incentive Structure of the Law of Affirmative Obligations, 72 Va. L. Rev. 879, 886-89 (1986). The stick that is used in Ybarra may generate an activity-level effect, see infra Part II.C, but the compensation offered to the victim does not create an incentive to create losses. It may, however, encourage those who have suffered losses to clain that they were caused by a group of attractive defendants. 
for insurance. ${ }^{31}$ We have seen that Ybarra-like liability has been assigned to such defendants as manufacturers, common carriers, and doctors, but this sort of refined group liability has virtually never been applied to a small number of individuals-perhaps because soine of these individuals are likely to be without liability insurance. ${ }^{32}$ It inay well be that passengers in an elevator do not face Ybarra-like liability because we do not wish to force so inuch risk on uminsured individuals. ${ }^{33}$ In slight contrast, factories along a polluted river may be subject to liability in the inanner of Ybarra, and they can more easily insure agamst such liability. I return to the importance of insurability in Section III.D.

It is tempting to enrich this explanation with a link to the distinction between negligence and intentional wrongdoing. One reaction to the question of why Ybarra nright be praised in the operating rooin but not in the elevator is that where intentional wrongdoing is concerned we are less inclined to invoke any form of group liability. ${ }^{34}$ If insurance were truly unavailable for intentional wrongdoing and always permitted otherwise, either as a matter of public policy or as a practical contractual ineans of controlling moral

31 The explanation that follows in the text might be reinterpreted as showing that in certain areas of law individuals are freed from liability where businesses are not. This distinction is discussed in Part III.A.

32 Homeowner's policies may well cover the kinds of group liability likely to threaten individuals, see infra notes $72-73$ and accompanying text (discussing possible liability for negligent salad preparation and smoking in a hotel room), and even overextraction in an elevator, but many individuals do not own homes (and thus do not carry homeowner's insurance policies) and do not carry other means of liability insurance.

33 Somewhat similarly, much as individual students or faculty members might aspire to create a law school "community," few would agree to share the losses associated with stolen backpacks and the like.

34 One explanation for this reaction is that the greater stigma attached to responsibility for an intentional wrong is (and should be) more cautiously placed on innocent shoulders. Another explanation may be that where there is intentional wrongdoing there may be no insurance, so that courts are especially disinclined to impose group liability. As for the first of these reasons, I am inclined to think that if this liability were shared, the stigma would largely disappear. More generally, it is not entirely clear that the distinction between negligence and intentional wrongdoing is doctrinally correct. If Ybarra had involved a wound carved into the patient's shoulder, so that the court were confident it had been intentionally and maliciously infiicted, would it have declined to find group liability? To be sure, it might not have used the doctrine of res ipsa loquitur, because that doctrine does seem (strangely) limited to cases involving negligence, see Prosser and Keeton, supra note $6, \S 39$, at 244; Restatement (Second) of Torts $\$ 328 D$ (1964), rather than intentional torts, but there may have been other routes to the same outcome. Note that res ipsa itself may be limited to cases where insurance is available to the defendant. 
hazards, then the connection would be a close one although a bit arbitrary. But inasinuch as the line between intentional (or uninsurable) and other wrongdoing is itself blurry, there is not inuch to be gained from emphasizing that the wrongdoing in the elevator was intentional whereas that in Ybarra was not. ${ }^{35}$

\section{OVEREXTRACTION}

\section{A. Designing Overextraction Rules}

It goes alinost without saying that overextraction must be limited or designed to induce the rational wrongdoer to confess. ${ }^{36}$ Overextraction would be somewhat wastefully chilling where an innocent person could falsely confess and extremely so where the wrongdoer was unaware of his own wrongdoing. A false confession allows an innocent person to pay where the wrongdoer should have paid. In contrast, where there is an unaware wrongdoer, all the innocents will forfeit their overextracted payments. Indeed, Ybarra itself is ill-suited for overextraction if the wrongdoer could have been unaware of his role in injuring the patient. The same might be true of soine polluters along a river; overextraction can be attractive only if the nature of the pollution is such that we can be sure that the polluter knows of its own misdeed, much as the pickpocket is surely self-aware.

Careful design is also needed where the wrongdoer will fear that confession brings on additional penalties. There is a tradeoff between the cost of preserving the confessor's anonymity and the cost of designing an overextraction scheme to inake confession attractive even to the wrongdoer who anticipates legal or extralegal penalties beyond those imposed as part of the overextraction rule. ${ }^{37}$ Where anonymity is costly, and further penalties are antici-

35 The distinction between intentional and other wrongdoing, with respect to group liability, is explored in Levmore, supra note 2.

36 I will use the term "confess" to include the anonymous return of what has been stolen. I might say instead "right the wrong."

37 In the pickpocket example the problem of extralegal sanctions may not arise if the passengers do not know one another. But if they do belong to a common community, and a confessor must fear further punishment, the incentive not to confess can be eliminated by maintaining the confessor's anonymity. The police officer might put each passenger in a separate room and even allow each passenger to drop an envelope into a box. The confessor would put the wallet in an envelope and preserve the secrecy of the "confession." 
pated by the potential confessing wrongdoer, the overextraction scheme needs to tailor its penalties (downward) in order to make confession attractive. One interesting implication of this requirement is that non-anonymous overextraction will be most difficult to design precisely where "communal responsibility" is normally most expected, namely where the target group members are closely bound. For overextraction to work in these settings, where extralegal sanctions are most likely, greater investments aimed at preserving anonymity will be worthwhile.

The cost of a failed application is of course greater the larger the target group from which overextraction is demanded. Yet, it is imperative that the target group contain the actual wrongdoer. ${ }^{38}$ In the elevator example, the target group can be narrowed by permitting passengers to choose between submitting to the overextraction scheme or to a search by the police officer. ${ }^{39}$ Other obvious

In other situations anonymity is less easily meshed with the need for a true confession. In the case of factories along a river, for example, the confessing polluter will need to show physical evidence at the factory site in order to demonstrate that it was really the wrongful polluter and not simply a member of the target group eager to pay actual damages rather than the larger overextraction amount. Anonymity is a convenient way to ease the fear that confession will be followed by costly tort suits. Presumably, a third party (or government agency) could be counted on as a confidence-maintaining stakeholder-and indeed the government has every reason to limit penalties as promised by the overextraction scheme in order to preserve the value of overextraction for the future. Similarly, if something is stolen from a teacher's desk, the teacher can use overextraction in order to encourage the return of the stolen item (where only the thief will know what was actually taken), and the teacher has every incentive to stick to the promised penalty in order to make overextraction work and thereby reduce future wrongdoing.

38 There is likely to be some social loss arising out of every extraction from an innocent party, and there are fewer such extractions the narrower the target group. Note that the Ybarra approach also prefers a narrow target group and that both overextraction and Ybarra must be sure that the wrongdoer is in the target group. In the actual Ybarra case, the court was (correctly) forced to include among those subject to the joint liability rule a nurse who was most unlikely to have witnessed much, but who might conceivably have done the wrong herself. See Ybarra, 154 P.2d at 688.

39 A disadvantage of permitting anyone who is willing to be searched to skip the overextraction rule is that the information-forcing component may be lost. A passenger who has not stolen the wallet, and who agrees to be searched, may well know the identity of the wrongdoer. On the other hand, Ybarra itself gives up the information-forcing idea where a defendant is able to show that it could not have done the wrong in question. Ybarra, 154 P.2d at 691 (stating that "all those defendants who ... might have caused the injuries may properly be called upon to meet the inference of negligence by giving an explanation of their conduct"). A more radical version of Ybarra might have permitted defendants to escape liability only if all but one of them could show that they were not the 
problems can be avoided if the victim is permitted to trigger overextraction only by agreeing to be searched and to contribute along with the other passengers in the overextraction scheme. The search removes doubt as to whether the victim has relocated his wallet. The payment might be understood either as a step toward ensuring that the victim does not complain carelessly or as a step toward encouraging the victim to internalize the cost imposed by the extraction scheme on the innocent passengers. If there are five other passengers, we might ask the victim to risk $\$ 600$ or $\$ 750$ rather than $\$ 150$ (if the claim is that $\$ 100$ was stolen) as a means of fully internalizing the costs imposed on the innocent passengers ${ }^{40}$ On the other hand, one reason the overextraction idea may fail is that the thief sometimes bears personal hostility toward the victim. The overextraction from the thief may succeed if the thief values his own $\$ 150$, for example, more than the victim's distress in losing $\$ 100$, but the same thief may be counterproductively encouraged (either to steal or to decline to return what was stolen) by the prospect of the victim's losing $\$ 600$ or more through an unsuccessful overextraction scheme. Stealing in order to trigger the overextraction rule can be seen as a kind of vandalism, and there is apparently some taste to commit such a wrong even though it does not enrich the perpetrator in the conventional sense. Moreover, if large payments are required of victims, some victims will fail to report wrongs of the very sort that might be solved and prevented by overextraction. ${ }^{41}$

tortfeasor, but such a strong-form, information-forcing rule was apparently unpalatable to the court in Ybarra.

The information-encouraging component of overextraction could be retained (even with the search option) by a rule that offered anyone who had been searched a reward for information. But see supra note 30 (considering the moral hazard associated with rewards).

40 The large payment may also minimize the danger of threatening fellow passengers that one will falsely report a theft. The problem of threats is taken up below in Part III.C.

41 Under existing legal rules, victims may under-report crimes because they consider the costs of reporting but fail to consider the social gains either from catching someone who is likely to commit future wrongs or from deterring criminals in general. On the other hand, victims may over-report because they do not consider the costs borne by innocent targets of any investigation (inasmuch as we lack perfect fee shifting in either criminal or civil cases). Because overextraction requires payments from likely innocents-in addition to the costs of being investigated-I pay special attention to the danger of over-reporting. 
Finally, although the overextraction idea remains a thought experiment, it inay be useful to point out that in the elevator example introduced at the outset of this article, the wrongdoer is not given much time in which to return what was stolen. Where evidence can be noved, time creates opportunity for shifting the blame. Thus, if the announced rule were that the overextracted funds would be returned if the wallet with the $\$ 100$ were returned within a week, then the clever wrongdoer might keep the stolen cash but (anonymously) mail the wallet to the victim, or perhaps even to another passenger. The innocent but rational recipient might then add $\$ 100$ to the wallet and return it to the stakeholder in order to regam the $\$ 150$ held by the stakeholder. One way to guard against this failure, and its attendant social costs, is to require the immediate return of the wallet (once the passengers have been separated). Another is to offer each passenger the opportunity to be searched rather than to pay the overextraction aniount-and then to keep secret the identity and number of passengers who refused to be searched. The rational wrongdoer would, in turn, be more likely to return what he has taken because he does not know to whom to mail the einpty wallet. More generally, it is necessary to guard carefully against false confessions because all members of the target group will gain if the confession is accepted..$^{42}$

\section{B. The Overextraction Puzzle}

The most obvious objection to the overextraction idea is that failure generates additional innocent victims. An argunient for overextractive liability rather than no liability at all (in the absence of firm evidence) is unlikely to succeed unless some experimentation suggests that in identifiable circunstances the threat of overextraction very often elicits a convincing confession. The puzzle of overextraction is not, therefore, why we do not find overextraction rather than no liability at all, but rather why there is Ybarra-like liability and yet no overextraction. Liability of the kind found in Ybarra and products hability law does, after all, also threaten inno-

\footnotetext{
42 And, more generally, delay offers an opportunity to frame or to encourage (false) confession by an innocent person. More modest group liability and individual liability also encourage such behavior, but there is no reason to leave room for such destructive behavior here. Other threat and side-bribe problems are taken up in Part III.C.
} 
cent defendants. In the absence of modest group liability, the apparent distaste for overextraction would not be puzzling. ${ }^{43}$

Overextraction offers some advantages that Ybarra cannot match. The first and most interesting of these is the incentive provided for the rational thief to confess. ${ }^{44}$ Both moderate group liability and overextraction encourage witnesses to come forward with information about a wrongdoer, but only a carefully designed overextraction scheme also encourages the rational wrongdoer to confess.

The second advantage of overextraction over more moderate group hability is that the latter but not the former provides an incentive to make false claims. Group, or joimt, liability as in Ybarra encourages false claims because the claimant gains "compensation." In contrast, a cautiously designed overextraction scheme offers no gain (and indeed a substantial loss) to the dishonest "victim,"45 at the same time that it offers a concrete, immediate reward ${ }^{46}$ to the confessing wrong-

43 The familiar preference for letting nine guilty people go free rather than punishing one innocent person reflects the view that it is morally reprehensible for the state to punish the innocent even if passivity on the state's part can lead to other detrimental consequences. The overextraction idea also risks punishing the innocent, because wrongdoers will not always behave rationally. On the other hand, a hidden social benefit of both overextraction and Ybarra-like liability is that investigation costs can be saved.

44 Inasmuch as I have suggested that vicarious liability and products liability can often be thought of as a kind of information-forcing group liability, there is the provocative question whether the overextraction idea could be useful in these fairly general contexts. If a car or aircraft explodes during normal use, instead of holding the manufacturer liable (even though the true wrongdoer may be the maker of a component) we might overextract from the manufacturer and every subcontractor unless one of these defendants could convincingly demonstrate that its wrongdoing caused the loss (in which case it would pay for the loss). The problem, of course, is that the negligent manufacturer of a component may not know that it wrongfully caused the loss in question. In the elevator example it is, therefore, not simply the presence of uncertainty (on the law's part) that makes overextraction intriguing but also the lack of uncertainty on the part of the actual wrongdoer. Vicarious liability and products liability law thus offer examples of the regular imposition of liability on innocents, but they do not offer broad fields of application for the overextraction idea.

${ }_{45}$ The possibility of false claims arising out of threats or side deals is taken up in Part III.C.

46 Criminal punishment is sometimes thought to be ineffective because many wrongdoers have short time horizons, so that they excessively discount both the probability of punishment and the burden of its administration far in the future. An interesting attribute of overextraction is that it offers (non-judgment-proof) criminals an immediate reward for confessions. 
doer. ${ }^{47}$ Overextraction, it should be noted, also offers a stronger incentive for witnesses to come forward and for potential target group members to be vigilant in a way that might produce the information that will help them escape overextractive liability. Indeed, one way to think of overextraction is as a system that piles on incentives without generating moral liazards. But to the extent that these strong incentives also create problems, and contribute to the social costs of failure, I will not count this stronger mcentive as an unambiguous advantage of overextraction over inore inodest joint liability. ${ }^{48}$

\section{The Chilling Effect of Overextraction}

I have coinpared (and presented the puzzle of) tlie absence of overextraction and the presence of Ybarra-like liability, with an einphasis on the relative advantages that overextraction miglit enjoy. At the same time, Ybarra and overextraction sliare some disadvantages. It is likely, lowever, that the common disadvantages are more serious for overextraction because the amount extracted from innocents (when the wrongdoer does not confess) is larger than it is under coinparable Ybarra-style rules. Thus, both Ybarra-like and overextractive liability might discourage people froin boarding elevators, but such an activity-level, or chilling, effect might be greater when the threat is of the larger, overextractive kind.

This comparison between overextraction and inore modest group liability suggests that overextraction might be most successful where inodest group liability is already found if only because the latter is likely to be used where the chilling effect is limited. We have seen that there are occasional examples of group liability

47 Overextraction can also be compared to the broader (noncompensatory) variety of de facto group liability. Through taxes, price increases, and other means, products liability and other de facto group liability also extracts from the innocent, generates potentially serious activity-level inefficiencies, and may be problematic where judgment-proof players are concerned (because these citizens will have no incentive to report on wrongdoers, for example, if their own tax liabilities are not increased at all). On the other side of the ledger, neither overextraction nor broad group liability encourages false reports by "victims," but only overextraction offers concrete incentives for wrongdoers to confess.

- 48 Thus, one would hardly prefer for the overextraction rule to demand $\$ 10,000$ from each passenger, rather than $\$ 150$, in order to strengthen the incentives to produce information. 
in the face of uncertainty in the operating room and on the loading dock, ${ }^{49}$ but such rules are much more familiar in the context of classroom, prison and military discipline. A teacher or officer might respond to wrongdoing by an unknown actor by imposing a communal curfew, for example, or otherwise withholding a benefit expected by all. The penalty may be intended to encourage peer pressure (in the future and even in the present if the penalty will be withdrawn in the event of a convincing confession by the wrongdoer) or the production of information. The remedy does not rise to the level of overextraction. If, for instance, a wrong has been committed in the barracks, we might expect a sergeant to announce that all weekend leaves are canceled, but we do not expect this to be accompanied by a promise that if the thief steps forward (everyone else will be free to go but) the thief will receive the lesser punishment of leave for only half the weekend. The group penalty inay encourage witnesses, build group sohdarity (or not), and even put peer pressure or guilt feelings on the culprit, but the rational, selfish wrongdoer may still keep silent.' Indeed, the punishment experienced by the confessing wrongdoer may well be greater if the confession follows the threat of group punishment than if it precedes it.

One obvious characteristic common to prisons, armies, and classrooms is that the participants cannot easily exit from their peer groups. This fits with an obvious explanation of why we rarely find much group liability, of either the Ybarra or overextractive kind, in the face of uncertainty about the wrongdoer's identity: there may be activity-level effects' encouraging people to steer clear of groups or locations where such liability might be imposed. We may find neither overextraction nor group liability in the case of pickpocketing on an elevator, because even modest group hability would severely curtail our sharmg of elevators with strangers.

I think it is easy to overemphasize the importance of this activity-level explanation for the disinclimation to use or even tolerate an overextraction rule. First, the argument assumes that the rule will rarely work. It is possible, after all, that the rule will work well enough to discourage pickpocketing so that people who previously avoided crowds because of the fear of pickpocketing will now be

49 See supra Part I.A. 
more likely to share elevators. Second, even where possible activity-level effects are likely to be small, we find little group liability. In short, the activity-level effect of group liability probably explains where and when we ought to find experimentation with such liability, even in its overextractive version, but it fails to explain the complete absence of overextractive rules and the occasional presence of liability along the lines of Ybarra..$^{50}$ In a world where one must fear assaults and other wrongs when sharing elevators with strangers, it seems unlikely that the increinental chilling danger posed by an overextraction rule would make much difference in our inclination to share a ride.

\section{Judgment-Proof Suspects}

A inore practical explanation for the absence of experimentation with immoderate group liability focuses on the overextraction requirement itself. If the stolen wallet contained not $\$ 100$ but rather $\$ 3000$, some passengers would likely have insufficient wealth to provide more than that amount. I set the original portrayal in an office building, and with $\$ 100$ missing, in order to illustrate the overextraction rule where such a serious judgment-proof obstacle was unlikely. But the problem suggests that we might be most likely to find group liability, even of the limited Ybarra kind, aimed at business enterprises rather than individuals, or applied where the penalty can be assessed in nonmonetary fashion.

If we are uncertain which of four factories has polluted a waterway, we might imagine shared liability of one kind or another; sub-

50 Moreover, there are other rules in tort and criminal law that can be described as information-forcing. Thus, criminal laws aimed at accomplices and conspirators can be described in this manner. Similarly, the criminal law doctrine of "constructive possession" can be understood as applying where one who is in control of a location is bound to have information about the commission of a crime in that location. In People v. Valot, 189 N.W.2d 873 (Mich. Ct. App. 1971), for example, the defendant had rented a motel room in which he was found along with four other persons; the discovered evidence suggested that at least one person had used and possessed a controlled substance in the room. The defendant was held in "control" of that room and therefore criminally responsible in the absence of any testimony from the five hotel room occupants. The best way to distinguish this case from one in which a homeowner or entrepreneur is charged on the basis of 'evidence that illegal drugs were used on the defendant's premises is to stress that in Valot, but not in many less intimate situations, the court can be certain that the defendant had information about the introduction of the drugs to the premises. 
ject to a defendant's ability to prove that it was not the polluter. ${ }^{51}$ This is not, it should be noted, closely related to market share liability as applied to pharmaceutical companies ${ }^{52}$ or as found in the famous case of Summers $v$. Tice $e^{53}$ - where one of two hunters shot the pellet that claimed plaintiff's eye-because in those cases all defendants behaved negligently and the uncertainty is limited to causation. In those settings liability can sometimes be applied in a way that will either seem quite fair and efficient across many cases or that will at least make no greater error than a rule of no liability. ${ }^{54}$ In contrast, the healtll professionals in Ybarra, the passen-

51 It is easy to imagine situations where defendants will have trouble developing information that another defendant was the real wrongdoer. And there will be many situations where any given blameless defendant will have difficulty proving its innocence. At the same time, it may be fairly easy for the wrongdoer to confess convincingly. We may not know when and where to look for evidence of pollution, for example, but the polluter may be able to show us exactly how it accomplished the wrongful pollution. In this situation an overextractive rule has promise. An Ybarra-style rule may be inferior because the gains from polluting may exceed the fractional share of the damages imposed on each player. A successful overextractive rule must threaten all members of the narrow target group with substantial liability so that the wrongdoer will find it worthwhile to confess and subsequently to bear both the costs of whatever (smaller) penalty is assessed and the costs associated with its inability to continue future undetected pollution.

A successful overextraction scheme also requires that the wrongdoer know of its own wrongdoing and that non-wrongdoers be unable to "confess."

52 Sindell v. Abbott Lab., 607 P.2d 924 (Cal. 1980), cert. denied 449 U.S. 912 (1980).

53199 P.2d 1 (Cal. 1948).

54 In the case of market share liability, where all defendants are negligent and all have caused some injuries, the problem is simply one of matching defendants with the victims they have injured. From a deterrence (and even a fairness) point of view, no harm is done with group liability because on average all will pay as they would in a world with no uncertainty. Saul Levmore, Probabilistic Recoveries, Restitution, and Recurring Wrongs, 19 J. Legal Stud. 691, 697-98 (1990). Summers is a different problem because it is not one where averaging across many victims is possible. But there is at least the argument that the "error costs" of making the wrong defendant pay can be expected to be the same as the error costs associated with absolving the defendants of liability. With no liability the real wrongdoér is underdeterred by $\$ X$, where $X$ is the victim's uncompensated loss. With joint liability of $\$ .5 \mathrm{X}$ on each hunter in Summers, the responsible wrongdoer underpays \$.5X and the unlucky (but negligent) codefendant overpays $\$ .5 \mathrm{X}$, so that the total error, measured in this way, is again \$X. Levmore, supra, at 693-94.

As a philosophical and logical matter one might argue that gronp hability is no more remarkable when it is applied to completely innocent actors than to wrongdoers who may not have caused the injury in question. This is apparently the unstated premise of Bush, supra note 21 . But from an error-minimizing or acceptability perspective the important difference between group liability in a case like Sindell v. Abbott Lab., 607 P.2d 924 (Cal. 1980 ), and that found in Ybarra or the elevator, is that mistakes are likely to average out only where the defendants are repeat players. Negligence on the part of all defendants 
gers on the elevator, and the factories located on a polluted waterway are likely to include a majority of non-negligent actors. ${ }^{55}$ In any event, if the factory owners are attractive defendants for group and even overextractive liability, it is in part because they are imagined as well-financed rather than as judginent proof.

Turning to nonmonetary extractions, the obstacle presented by judginent-proof individuals can be avoided by offering an alternative to casl payment. Elevator passengers could be told that they must either submit to a moderately intrusive personal searcl or pay an amount greater than that in the stolen wallet. ${ }^{56}$ Inasmuch as the overextraction rule is improved witl a sinaller target group-so long as this target group is certain to mclude the thief"volunteers" to be searched are welcome as a means of narrowing the group from which to extract. In the extreme case, if all but one passenger agree to be searched, the police will surely have probable cause to search the remaining passenger, who in the stylized hypothetical will be identified as the thief.

In other settings, where searches may be less successful tools of investigation, the nonmonetary good to be extracted is of the more obvious and general kind. Each passenger could be threatened with some amount of incarceration or some hours of community

might be taken as a proxy for situations in which repeat play, or recurring involvement, is likely.

55 There is something of a design problem if more than one factory may be a wrongful polluter. Each confessor would need to show how much it contributed to the pollution problem, and overextracted payments should be returned only when the aggregate amount to which the parties convincingly confessed equals the amount thought to have been wrongfully discharged.

56 There may be some objections to such a search-or-pay scheme on constitutional or other grounds, but for the sake of argument I will assume that we would permit such a "tax" on the right not to be searched. There is no doubt the law can impose Ybarra-like liability, on the blameless and blameworthy alike, and I would thimk there little doubt but that one could escape such liability by showing that one is blameless-even if the manner of proof involves agreeing to a search that could not otherwise be required. The question may be more complicated if wealth turns out to be a good predictor of who chooses to be searched and who pays "taxes." More generally, overextraction schemes can be designed as taxes, but if these taxes are often imposed on those who cannot be expected to have the means to pay them, and if a loss of liberty is the penalty for the nonpayment of taxes, there will be serious constitutional objections. But masmuch as I am not suggesting that we enact such an overextractive scheme, and there is not something plainly lawless or unconstitutional about a narrowly designed overextraction rule, I will not dwell further on the relationship to the law of search-and-seizure, unconstitutional conditions, due process or extortion. 
service. Anonymity for the "confessing" wrongdoer is now not as easy to offer; there would simply need to be a credible promise that if the wrongdoer returned the wallet, the innocent passengers would owe no time, and the wrongdoer would serve something less than the ainount earlier threatened. The law would have every incentive to make good on this promise, and the wrongdoer could rely on it, knowing that a breach of this promise would ruin the overextraction rule in the future. ${ }^{57}$ Theoretically, the threats can be alternatives offered to all target group ineinbers so that each passenger might choose among incarceration, commumity service, and a monetary payment. The important thing is to insure that every alternative threat overextracts from the thief. If the thief prefers a inonth in jail to returning $\$ 3000$, then a inonth is an insufficient threat-and the consequences are rather serious for all the innocent passengers.

I think it safe to say that while we might expect such threats (of either the Ybarra or the overextractive type) froin occupying armies or prison wardens, who might not value the individual and social loss associated with incarcerating or otherwise penalizing innocent people, it is inost unlikely that such threats would be used in the normal course of governing, and not unlikely that such threats would be constitutionally impermissible even if democratically desired. ${ }^{58}$ A cynical observer might say that our prosecutors often use such threats, perhaps in the form of criminal conspiracy charges, but so long as they are aimed not at people "like us" in an elevator but instead at a social or a criminal class remote from our experiences, few objections are heard. Put differently, the very idea of incarceration for untimely elevator travel (and for a subsequent unwillingness to be searched) would be shocking and

57 More generally, the overextraction idea unravels if the wrongdoer's confession is inhibited by the prospect of implicit penalties. In the elevator illustration, anonymity guarded against this problem, but in other situations there would need to be a credible promise to the confessor. Superficially, this may seem difficult to accomplish because even if the stakeholder keeps the wrongdoer's identity confidential, there would seem to be reputational losses to all members of the group (one of whom is a known wrongdoer). But this iguores the fact that knowledge of the original loss or wrongdoing already threatens the reputation of all members of the group. Moreover, the institution of an overextraction scheme would over time reduce the stigma associated with this kind of collectively imposed liability.

58 The complication is that the scheme can be described as a tax, with incarceration and the like only required of those who do not pay their taxes. 
unpalatable to most citizens. Hence the overextraction idea must either deal with the judgment-proof problem in a different manner (or be used to emphasize that similar threats seem less shocking to most citizens when applied in a different arena).

Returning to the problem of designing an overextraction scheme when a substantial property crime is at issue and the wrongdoer may be judgment-proof (for a judgment or threat in the range of the property at risk), the size of the nonmonetary substitute threat that would be necessary to effect the overextraction idea is likely to threaten too great a social loss. This point may be clearer in (unpopular) econonnic terms. Monetary transfers from the innocent inembers of the target group to charities or to government programs, as would occur when the overextraction rule fails, yield social losses inuch less than the private losses experienced by these individuals. ${ }^{59}$ But if monetary transfers cannot be used because targeted wrongdoers may be judgment proof, then available substitute threats (such as incarceration) will nearly always be accoinpanied by relatively large social losses. This suggests that the overextraction idea is probably best (but still shockingly) thought of as applied with alternative threats. When $\$ 100$ is stolen we nright demand $\$ 150$ from every passenger, but when $\$ 3000$ is stolen the systein night need to require each passenger to choose whether to pay $\$ 3500$, serve six months in prison, or work 1000 hours at a job offered by the state. Again, all these debts would be forgiven if (or when) the wrongdoer returns the nrissing wallet and inoney, and none of these alternatives need be cliosen by a passenger who consents to a search. In slort, the judgment-proof problein creates the need to extract penalties in forms that yield greater social costs, but by offering choices (including monetary payments) these costs may be controlled. Still, these costs are a good proxy

59 The idea is that the cost to the innocent loser is at least somewhat offset by the gain derived from the use to which the funds are put. In the case of theft itself, it is therefore sometimes said that the social loss comes not from the involuntary wealth transfer (an assessment of which requires interpersonal utility comparisons) but rather pertains to the costs of precautions taken against theft and the importance of secure property rights in encouraging socially valuable work effort. Still, it is noteworthy that the most salient costs associated with an unsuccessful overextraction scheme are private costs that are likely to exceed social costs. Moreover, the social gains from successful overextraction, in the form of deterrence and reduced investigation costs, do not fall on identifiable winners who can therefore be expected to lobby in favor of such schemes. 
for the political unacceptability of most applications of the overextraction (and even the Ybarra) idea.

\section{E. Private Bargaining for Overextraction}

It is not terribly puzzling, I think, that we find no private bargains for overextraction. In the elevator case, for example, there is no reason for an innocent passenger to think that by agreeing to be searched (or to pay $\$ 150$ in an overextraction scheme) other citizens will agree to do the same in the future. It is possible that upon entering the elevator most would agree to participate in an overextraction scheme, and especially to a scheme in which one could avoid monetary liability by agreeing to be searched in the event of a crime, but once the crime is already committed, and the victim is a stranger, there is much less to be gained froin voluntary participation. This is precisely the situation where legal rules are most often needed as precommitinent devices. And through the purchase of insurance contracts people do consent, in a manner of speaking, to sharing agreements before entering elevators. Overextraction, however, is not generally a part of these contracts. I return to the relevance of insurance practices below in Part III, with a more general discussion of the puzzle of (the absence of) overextraction rules.

But the puzzling comparison of overextraction and more modest, Ybarra-like, group liability (where the puzzle is that the latter is familiar while the former is unknown) suggests that where modest group liability is threatened, a majority of such a target group might lobby or vote ${ }^{60}$ for the alternative of an overextractive scheme in order to avoid group hability for the actions of a wrongdoer in their midst. Most people would surely object to paying any amount after a fellow passenger was pickpocketed. But if offered a choice between paying twenty dollars, as called for by the Ybarra rule, or $\$ 150$ (with a much greater likeliliood of the money being refunded), as is consistent with the overextraction rule, the latter may at least soinetimes be preferable. ${ }^{61}$. Again, the overextraction

60 Bargaining alone would do no good, because the wrongdoer might hold out.

61 To the extent that witnesses do not come forward because they fear retaliation, it is possible that $\$ 150$, rather than $\$ 20$ or nothing, will help overcome this disinclination. Thus, although passengers might privately prefer less liability rather than more, there may be a social reason for preferring overextraction. The discussion in the text, however, focuses 
puzzle is why we do not find overextraction in legal systems that have already decided to impose Ybarra-hke liability.

I can barely imagine firms along a river, subjected to Superfund liability or other group liability, lobbying for an overextraction scheme. More imteresting, perhaps, is the converse possibility that if overextraction were used in this situation, the target group could bargain out of the overextraction scheme. Thus, if overextraction were tried but found too costly, perhaps because the target group alone recognized that false confessions can be made to look convincing, there would be the convenient escape hatch of a private agreement to clean up the river or compensate plaintiffs (or even contribute to political insiders) in order to avoid overextraction. ${ }^{62}$

Fimally, there is the possibihty that private bargaiming will lead to overextraction because victims miglit pay other parties to participate in such a scheme. The victim in the elevator might offer a nonrefundable ten dollars to each passenger as encouragement or compensation for undertaking the risk of contribution or agreeing to be searched. But inasmuch as private bargaining cannot, presumably, coerce unwilling participants, the only point of such a payment by the victim is that the victim must hope that the thief will fear participation (most simply in the form of consent to be searched) sufficient to generate probable cause for searching the thief. The rational thief therefore might agree to participate in an overextraction scheme only if everyone else does so as well. ${ }^{63}$ One problem with this kind of private bargaiming is that it might subsidize and thus encourage thievery. The victim may be initiatimg or preempting a kind of extortion scheme that is socially undesirable even if privately worthwhile. A thief might simply steal with the.

not on the argument for overextraction but rather on the possibility that when faced with modest group liability, target group members will prefer overextraction.

62 Such bargaining might also take place in the shadow of overextraction. An industry might agree to clean a river or pay claimants in order to forestall a legislative move to overextraction.

63 If the victim's payments encourage consents to searches, rather than participation in an overextraction scheme, then there is the general question why victims do not try this approach. Inasmuch as my focus is on group liability, I assume that some innocent passengers might prefer overextraction to search.

Note that the thief will probably not be alone in agreeing to participate only if others agree as well. An interesting question is what the thief will do if the passengers are separated before this $\$ 10$ offer is made. 
intention of anonymously returning what has been taken after receiving the ten dollar subsidy. If this danger is combatted with a rule of refundability, so that the ten dollars is retained only in the event that the thief does not return the wallet (so that the rational thief will return both the wallet and the ten dollars in order to reclaim his $\$ 150$ ), the scheme is nothing more than an overextraction rule with a forty dollar (rather than fifty dollar) margin of safety. This margin needs to be large enough to overcome the fact that the wallet itself (and its other contents) may be of some value, the likelihood that the wrongdoer takes pleasure in the victim's distress, and small evidentiary doubts. These doubts can arise out of perfectly guileless behavior; the victim might conservatively say the wallet has $\$ 100$ in it when in fact it has $\$ 140 .{ }^{64}$

\section{F. Collusion and Plea Bargaining}

I have stressed that the critical aspect of overextraction is its influence on the rational wrongdoer, but at the same time I have hinted that there is something circular about this argument. If overextraction is a clever tool in the fight against wrongdomg, then the truly rational wrongdoer may not return wallets or otherwise confess, precisely in order to disabuse the rest of us of the idea that we have a useful tool. Inasmuch as unsuccessful overextraction imposes substantial social and private costs, wrongdoers will need to resist but occasionally the short-run temptation to confess in order to ruin any possible case for the overextraction rule.

But, again, it is easy to make too much of this argument against overextraction. The response of any individual wrongdoer will contribute so little to the overall success of an overextraction rule that it is surely fair to describe the rational pickpocket, for instance, as inclined to return the wallet when faced with the terms of the overextraction rule. This is what we nornally mean by rationality. It is of course true that wrongdoers im general miglit wish to collude in order to ensure the failure of an overextraction sclieme. But. such collusion is nearly impossible not only to the

64 We can imagine imposing a penalty for misstating the value of what has been taken, but this step is probably made unnecessary by the requirement that the victim participate in the overextraction scheme. This internalization requirement addresses the case of overstatement as well as understatement by the victim. 
extent that there is "no honor among thieves," but also because the "rational" thief will simply defect from a collusive agreement.

The evolutionary success of plea bargaining offers a doubly apt analogy. Cooperating criminals might agree (or might signal to one another by acting as if they had agreed) to refuse prosecutors' settlement offers and to demand jury trials in order to force the state to expend greater resources in trials. These expenditures would almost surely inake it impossible for the state to proceed against as many defendants as in a world with a great deal of plea bargaining unless trials becaine more "casual" or less adversarial. 65 The criminal enforcement and justice systein might not collapse if all plea bargains were refused by defendants, but it is hikely that in the short-run criminal defendants would be better off if a very large number of them refused settleinent offers and insisted on jury trials. But the fact that most criminals might wish they could collude in refusing plea bargains does not mean that it is rational for one criminal defendant to refuse to plea (or even to insist on a jury trial). And we do not dismiss the idea of plea bargaining simply because criminals wish they could cooperate in order to create institutional difficulties.

Plea bargaining is an especially good example here because in one respect plea bargaming itself is an example of the overextractive ideal. A prosecutor may induce a guilty plea with the threat of extensive investigation, multiple charges, and greater penalties in the event that the defendant opts for, and loses at, a trial. Similarly, an overextractive rule threatens the wrongdoer with a greater penalty in the event that there is no confession and with a lesser penalty in the event of confession. Both schemes seek to encourage rational confessions and both seek to guard against false

65 See Robert E. Scott \& William J, Stuntz, Plea Bargaining as Contract, 101 Yale L.J. 1909, 1916 (1992) (assuming tradeoff between alienable right to an elaborate trial and inalienable right to a more casual trial process and arguing that most defendants would prefer former); John H. Langbein, Land Without Plea Bargaining: How the Germans Do It, 78 Mich. L. Rev. 204 (1979) (describing advantages of nonadversarial system with guilty pleas). The collusive strategy would need to include the deniand for jury trials because there is good evidence that trials without a jury could be relatively short and yet anything but casual and nonadversarial. See Stephen J. Schulhofer, Is Plea Bargaining Inevitable?, 97 Harv. L. Rev. 1037 (1984) (describing a bench trial syștem used in Philadelphia). 
confessions. ${ }^{66}$ And in some sense both overextraction and plea bargaining attempt to reduce enforcement costs because, at least theoretically, all uncertainty could be eliminated witli greater information-gathering effort. Nevertlieless, plea bargaming is not quite an illustration of an overextraction rule. First, the central feature of the overextraction idea is that it is always rational for the wrongdoer to confess. The same cannot be said for tlie criminal (or tort) defendant offered a settlement. Moreover, plea bargaining is not a subset of overextraction because the former process does not generally seek to force out the identity of the wrongdoer. It is difficult to argue that plea bargaining is a method of identifying a wrongdoer within a group of otlerwise innocents, but it is plausible that an overextraction scheine could induce a pickpocket to return stolen money.

This comparison between plea bargaining and overextraction highliglits the puzzling absence of the latter alongside the popularity of the former. One way to think of the overextraction idea is as a mixture of two familiar and accepted strategies, information-forcing group liability and plea bargaining. The evolutionary survival of these strategies shows that at least soine legal systems are prepared to threaten innocents, bargain with wrongdoers, and exploit the state's resources as leverage to gam confessions. Overextraction may be offensive, but it does not seem to be so for novel reasons. ${ }^{67}$

${ }^{66}$ This is not the place to review the literature on plea bargaining, but every reader of law reviews knows that there is serious doubt as to the "rationality" of some plea bargaining and even more doubt as to the system's ability (or incentive) to block guilty pleas by risk-averse innocent defendants. See, e.g, Albert W. Alschuler, The Changing Plea Bargaining Debate, 69 Cal. L. Rev. 652, 716 (1981); Stephen J. Schulhofer, Criminal Justice Discretion as a Regulatory System, 17 J. Legal Stud. 43, 74 (1988). In principle, our legal system requires that there be a factual basis for a guilty plea, see, e.g., Fed. R. Crim. P. 11(f), and at least theoretically a judge (or an ethical prosecutor) could require sufficient detail to increase the likelihood that such pleas are only bargamed for and entered into by the truly guilty. In the face of such a serious rule, there will remain a residual problem of collusion between the prosecution and the defense, much as the overextraction idea will always suffer from the problem of under-reporting or false "confessions" by victims. See infra Part III.C.

67 A critical difference between plea bargaining and overextraction may be that only the latter intentionally strikes at the innocent. Plea bargaining is found quite distasteful when prosecutorial threats induce innocent people to "confess" rather than to proceed with lengthy investigations and trials and their attendant costs. On the other hand, inasmuch as 


\section{The Absence of Overextraction}

I have suggested that, because the disadvantages of overextraction differ from those of more modest group liability only in degree, there is something of a puzzle about the presence of the latter but not the former. Both the Ybarra and overextractive versions of group liability offend our wish to protect rather than penalize the innocent; both run into problems where judgmentproof defendants are concerned; and both risk generating activitylevel imefficiencies. The overextraction rule does more of each of these three things, but at least in principle the functional, moral, and jurisprudential arguments against overextraction and against expanding Ybarra are comparable. To the extent that the legal systein is prepared to deal with its inability to identify a wrongdoer by targeting a group of persons that includes the wrongdoer as well as innocents-perhaps because soine of these innocent people have information about the identity of the wrongdoer-it inay be better to take the more immoderate step of overextraction than either the more obvious step of inere group liability or the more familiar step of de facto broad group liability. ${ }^{68}$ The puzzle that I atteinpt to clarify in this Part concerns the absence of overextraction in a world where group hability is common.

\section{A. Hidden Costs}

One obvious problem with the political or judicial adoption of an overextraction rule is that the immediate costs of unsuccessful overextraction are painful to conteinplate. In contrast, if overextraction is successful, soine of its benefits are hidden because they involve the decline of activities such as pickpocketing. ${ }^{69}$ Similarly, the popularity of broad but modest group liability can be ascribed to the dispersed and often hidden costs of such burdens. Much as the enactinent of a government spending program is often

Ybarra-like liabihty also knowingly takes aim at the innocent (along with the blameworthy), there must be something more to the objection to overextraction.

68 These broad (tax and regulatory) schemes differ, once again, from Ybarra and the elevator case in that they generally provide no immediate compensation to the claimant.

69 Instances of unsuccessful application of the overextraction rule are also likely to be more salient than occasions when the rule works and all imocent players enjoy full refunds. Note that some of the benefits of overextraction, such as reduced investigation costs, are also available with more modest group liability. 
explained as the product of encouragement by coordinated beneficiaries (who face little opposition from relatively dispersed taxpayers who pay for the program), we can explain many loss-sharing arrangements as satisfying relatively organized interests at the expense of less identifiable, dispersed losers. The puzzling absence of overextraction in a world where there are other group liability schemes can in this way be solved with the observation that the. relative advantages of overextraction go unnoticed, while the costs tend to attract attention. ${ }^{70}$

A slightly different and inore cynical version of the hidden costs explanation is that most people (including legislators and judges) abhor forcing contributions froin innocents only when they can identify with these innocent losers. When the defendants are businesses, for example, the reaction to group liability is less negative than where individual defendants are concerned (perhaps because the effect of such liability on prices is hidden or not fully understood). It is no accident, I think, that outside of the medical context the cases which most reseinble (or even expand upon) Ybarra involve defendants that are common carriers, warehouse owners,

70 A related argument is that legal systems do well to avoid large, salient costs by favoring rules that are relatively tolerant of factfinding (and other) errors. The burden of proof that must be met to justify criminal penalties and the evolution toward comparative negligence are two examples of developments that can be understood in this manner. In the criminal law example, the law is apparently and understandably concerned about levying a criminal penalty on an innocent person whereas the comparable civil case involves mere error minimization across like plaintiffs and defendants. Somewhat similarly, comparative negligence can lead to error in the assignment of responsibility, but a rule incorporating contributory negligence as a complete defense (or not) is almost by definition more likely to turn a small error in factfinding into a large monetary error or other injustice. In any event these examples may suggest that overextraction is not used because it threatens to make large errors if, for example, the overextracted amount is (even) slightly too small or the value of anonymity is underestimated.

I must leave for another day the question of when and why legal systems are "error sensitive" in the manner suggested. For the present, however, it is important to see that overextraction need not always be error sensitive. There is, for example, not a single correct amount to overextract in the pickpocketing case, but rather a range over which there will be enough at stake to elicit a rational confession but not so much as to create unnecessary judgment-proof problems. But the larger point is that law often does favor rules that are more error-sensitive than alternatives. Thus, we use a preponderance-of-theevidence rule with the effect of a tipping point, so that if a factfinder finds the defendant $51 \%$ likely to have done something then this defendant might pay $100 \%$ of plaintiff's damages. A more probabilistic rule might have had this defendant pay $51 \%$ of plaintiff's damages. The probabilistic rule would not be error-minimizing, but it would obviously guard more carefully against large errors. See Levmore, supra note 54, at 703-04. 
manufacturers, and other business enterprises. And to the extent that the most important examples of group liability are accomplished through vicarious liability or products liability law, as suggested earlier, ${ }^{71}$ judgments normally fall on business enterprises rather than (uninsured) individuals. Ybarra itself involved a hospital, doctors, and other health professionals who are normally insured. In contrast, the decisions most striking in their refusal to follow or to expand upon Ybarra involve preparers of turkey salad, ${ }^{72}$ smokers in a hotel room that later catches fire, ${ }^{73}$ and jeering onlookers who might know the identity of the person who assaulted a misbeliaving police officer ${ }^{74}$ - cases where the defendants are nonbusiness individuals. ${ }^{75}$

In short, a simple-if overtly political-explanation for the absence of group, information-forcing, and even non-overextractive liability in the elevator case may be that there is virtually no precedent for such liability where mere individuals are concerned. On the otlier liand, inasmuch as we do not find overextractive scliemes aimed at corporate defendants, where such schemes might in fact work best, the argument about hidden costs falls short of explaining the puzzles associated with the overextraction idea.

71 See supra Part I.B.

72 Samson v. Riesing, 215 N.W.2d 662 (Wis. 1974).

73 Fireman's Fund Am. Ins. Co. v. Knobbe, 562 P.2d 825 (Nev. 1977) (declining to impose liability for fire damage where four smokers had been in the hotel room where fire began but where many hotel employees also had keys to the room).

74 Clift v. Nelson, 608 P.2d 647 (Wash. Ct. App. 1980) (refusing to find liability where many onlookers jeered at misbehaving police officer and some may well have known identity of wrongdoer who assaulted officer).

75 The correlation between insurance coverage (more likely carried by businesses than individuals) and liability is considered in Part III.D.

Note that busmesses are repeat players and therefore more likely to collude over time (im order to create uncertainty and thus avoid liability while reducing precaution costs). Another possible explanation for the disinclination to use group liability where individuals are concerned is that there are natural, self-serving reasons to take precautions in many of the nonbusiness cases. Thus, a parent might be expected to take care in food preparation (even knowing that wrongdoing would be impossible to trace), because the preparer's own child will partake in the jointly prepared food. But neither of these distinctions seems to explain more than a modest subset of the cases, and the latter suffers from the problem that liability for defective products is hardly reduced where a manufacturer's executives use the product in their consumer lives. 


\section{B. Proportionality}

The law and economics literature offers many examples where optimal deterrence can be preserved or even best accomplished with large penalties, only occasionally applied. Criminal law, tort law, and popular reaction do not, however, appear to be entirely sympathetic to such a probabilistic view of justice. ${ }^{76}$ Instead, there is an important element of proportionality im much of law, so that greater wrongs are expected to yield more severe penalties. The overextraction idea is at odds with this norm because it requires larger extractions for smaller wrongs in order to make room for offers that wrongdoers will not dechine. It will often be the case that greater penalties need to be attached to suspicions than to known wrongdoings, and this will violate the proportionality norm. Thus, the overextractive threat against four factories on a polluted waterway may far exceed the direct hability that would be applied if there were no uncertainty and a single factory were found to be wrongfully polluting the waterway to the same degree.

The proportionality theme is clearer when used to explore the overextraction rule's assumptions about the "rational" wrongdoer. If wrongdoers always behaved rationally, then an overextraction scheme could solve virtually every crime. An armed robbery of a convemence store might be followed by an announcement that all persons fitting the general description of the robber and living within a certain number of miles of the store will serve thirty years in prison unless the wrongdoer convincingly confesses and in return receives a "reduced" prison term of twenty years as befitting the crime. If wrongdoers behave rationally, there will never be an overextraction. One problem, of course, is that the rational wrongdoer will correctly surmise that our society will not tolerate this overextraction from the innocent. Even if the costs of crime (to the innocent) were demonstrably greater than those associated with this brutal overextraction, nevertheless the calculated, large-

76 Thus, punitive damages might be expected where the wrongdoer could easily have escaped detection, but in fact punitive damages are most likely where the wrongdoer is brazen. See Malcom E. Wheeler, The Constitutional Case for Reforming Punitive Damages Procedures, 69 Va. L. Rev. 269, 282 (1983) (noting that "the jury must find that the defendant acted maliciously, in 'wanton disregard for the rights of others,' with 'flagrant indifference' to the rights of others, or in an 'outrageous manner' ") (citations omitted). 
scale, state-sponsored incarceration of innocents is preposterous to imagine and practically, if not academically, impossible to recommend. Not even occupying armies feel unconstrained about the level of communal responsibility they can impose.

The proportionality theme carries some explanatory weight, but not enough to warrant inuch more attention. The proportionality norm may be a useful descriptive (and normative) tool but it is also one that most citizens are prepared to sacrifice for other goods or principles when convinced of a worthwhile tradeoff. Plea bargaining itself can be described as interfering with the proportionality aspiration, and most citizens (and certainly lawmakers) accept plea bargaining as a worthwhile evil or even as a genuine good. One important difference may be that plea bargaining bends the rule of proportionality by generating some low punishments (for those who plead), whereas overextraction departs from the ideal in the other direction. On the other hand, plea bargaining must surely mvolve prosecutorial threats of large pumishments-and thus deviations from the proportionality norm-for those who go to trial. Plea bargaining and overextraction can therefore both be said to depart from the proportionality norm (and perhaps in the same direction), and yet only plea bargaining has experienced evolutionary success.

\section{Side Deals}

One possible problem with the overextraction rule is that it might subsidize wrongdoing if the wrongdoer can convince other members of the group that he will behave irrationally unless the group rewards him. In the elevator case, for example, the true thief might contact one or two other passengers ${ }^{77}$ and promise to return the wallet containing the money in return for $\$ 100$. If the implicit threat is credible, the innocent passenger might pay $\$ 100$ to the threat-maker in order to retrieve the $\$ 150$ already paid to the stakeholder. If there is reason to fear such side deals, then the overextraction idea could easily do more harm than good.

77 The thief would not want to hustle all passengers because if more than one target runs to the police, the wrongdoer will run a serious risk of prosecution. I imagine the sophisticated wrongdoer choosing one vulnerable fellow passenger as a mark. If the overextraction plan is carried out immediately, see supra text accompanying note 42 , such tailored threats are unlikely to be made. 
It is always difficult to evaluate the credibility of such threats because so much depends on the victim's and criminal's attitudes toward various types of risk and on the threat-maker's persuasiveness. And it is difficult to see why a threat to behave "irrationally" should be taken more seriously than many other threats which would unravel familiar legal rules.

The obvious problem with this threat from the wrongdoer's point of view is that the target will know that the overextraction rule makes it worthwhile for the wrongdoer to return the wallet if the target ignores the threat. Consider what the target must believe in order to pay the $\$ 100$ as deinanded. The target must believe that the threat-maker is truly the wrongdoer and thus in control of the overextraction fund; that the threat-maker will really fail to return the wallet if the target refuses to pay as advised; and that the threat-maker will return the wallet if the target pays as instructed. The latter condition is itself a serious obstacle because if the threatmaker has recklessly threatened more than one target, ${ }^{78}$ then once the target beheves the second condition, the target must also believe that other threatened targets will pay as instructed. If such threats were legal we could imagine making them credible, but it is difficult for a threat-maker who must avoid detection to overcome the obstacles to collection and incredibihty.

For the prospect of this threat to explain the absence of an overextraction rule, we must think that the overextraction rule would itself add significantly to the likelihood and success of such threats. An enterprising criminal might simply call randomly selected citizens or accost fellow passengers in elevators with the threat of inflicting bodily harm in the future unless some payinent is made. There is some chance that these threats will be believed, and some chance that bodily harm will occasionally be inflicted if only to make such threats more credible in the future, but there is hittle reason to think that the leverage offered by the overextracted pool of money adds much to a criminal threat-maker's arsenal. Some credibihity may be added by the fact of the prior pickpocketing, because the target knows that the threat-maker is likely to be the saine person and has reason to believe, therefore, that the threatmaker is im fact a person capable of a calculated crime. But the

78 See-supra note 77 (explaining why such behavior would be reckless). 
same is true of any random threat-maker who adduces evidence of his criminal past.

A similar problem is that the victim might threaten other passengers, perhaps simply by telling them of the crime and asking for compensation, agreeing in return not to report the crime. ${ }^{79}$ Passengers who fear that overextraction will be unsuccessful might be tempted to pay for the threat-maker's silence. But again, it is difficult to see why this threat should be more credible than other random threats. The target knows that if the victim does report the wrong, the victim must risk at least as much as the target,,$^{80}$ and there is no reason for the target to think that the victim is really more optimistic about the success of the overextraction scheme. than is the target.

A different sort of threat may be associated with both overextractive hability and moderate group.liability. Faced with group hability (of either twenty dollars or $\$ 150$, following the theft of $\$ 100$ ), one passenger might threaten another with a false accusation unless the target pays some amount to the threat-maker. Inasmuch as such individualized fingerpointing may only confuse the matter (because other passengers meanwhile also report things, real or manufactured, in an attempt to shift liability), the best threat might involve two or more passengers' colluding in order to implicate another. Such collusive arrangements might aim to place blame on a particular passenger or might take the form of a threat in order to extract a side payment from the target (perhaps to cover the group liability). At a bare mimimum there is the problem that passengers facing group liability, rather than no liability, will shade their testimony in ways that implicate an innocent passenger. In short, secondary wrongdoing is surely more likely in the face of group liability than not, ${ }^{81}$ but again the increinental effect of group liability on threat-making (or generating false accusations) seems

79 In a setting different from the elevator, a "victim" might be able to identify fellow group members in advance and threaten to report a fictitious crime. This strategy is particularly dangerous if advanced against more than one target.

so See supra Part II.A for discussion regarding whether the victim should contribute the same amount as other group members or some multiple of this amount.

81 Theoretically, threats are problematic even where there is no group liability because the victim might pay one passenger to substantiate a story accusing a third passenger. But it seems that there is a kind of endowment effect working in threats, or at least in shaded testimony. It may be easier to influence the testimony of an "innocent" passenger when 
rather small. I would be surprised if a serious objection to Ybarra (or to overextraction) was that it encouraged wrongful, collusive side deals among defendants. If threat-making is a greater problem for the overextraction scheme, it must be because that threat could be credible without collusion among two players. The collusion that is necessary to make the second kind of threat or false testimony work is largely controlled by the increased danger to each threat-maker (or false testifier) from bringing im an accomplice. .2 $^{2}$

In sum, I am mclined to think that although there are interesting side deals to consider in the shadow of an overextraction scheme, these destructive arrangements seem not to be encouraged by overextraction itself. Indeed, it is possible that problematic threats are equally likely with Ybarra-style liability, ${ }^{83}$ and such threats may be a far more serious problem in everyday life where there is no particular prospect of group liability, but simply risk averse, vulnerable citizens. On the other liand, because side deals and the credibility of threats are sufficiently difficult to evaluate, ${ }^{84}$ we might

that passenger is already threatened with liability in the event that no single "wrongdoer" can be identified.

82 There is also the less pernicious possibility that the victim will despair as the deadline for confession approaches if the overextraction scheme is one in which immediate confession is not required. See supra text accompanying note 42 (discussing need for immediate confessions in some settings to prevent strategic behavior by wrongdoer). The victim cannot be permitted simply to withdraw the claim (or otherwise undo the overextraction scheme) because wrongdoers will then delay or decline to return what they have taken. But the victim is often uniquely' situated-and needs no accomplice-to reproduce what has been taken and to "return" this reproduction to the stakeholder in order to gain the return of the larger, overextracted amount. To guard against this problem, the stakeholder might at the outset announce not only the length of the waiting period in which the wrongdoer can return what has been taken, but also that the return of the stolen property will not be disclosed until the end of the period. In this way there will be little reason for the victim to change strategies prior to the end of the waiting period.

83 The greater liability associated with the overextraction rule is likely to encourage attempts to.assign blame. On the other hand, this liability is uncertain, and innocent passengers may therefore simply await confession by the wrongdoer. In contrast, although the Ybarra rule leaves open the possibility that "true" information will be forced out (so that liability is again uncertain), an "innocent" passenger may think this relatively unlikely and may therefore be more tempted to shift blame with false testimony.

84 For example, in the absence of contrary data, one might have reasoned that blackmail and kidnapping (or even terrorism in general) were crimes not worth worrying about. Blackmailers must suffer from the problem of convincing their targets that they will not repeat the threat. And kidnappers not only must arrange for an untraceable transfer of funds but also must convince their targets that they have reason to return the victim alive 
allow for the possibility that overextraction rules have not materialized because of these threats. Similarly, the scope of more modest group liability may itself be dictated by a combination of the problems of side deals, threats and false claims. ${ }^{85}$

\section{Insurability}

A potential clue to the puzzle before us is that an overextraction rule needs to block or forbid insurance coverage for overextraction. The key element of the overextraction idea is of course that the rational wrongdoer will prefer confession over retention of illgotten gains, and this element will be missing if an insurer bears overextractive liability. Thus, an overextraction rule would require some expansion of the class of judicially or legislatively uninsurable risks. ${ }^{86}$

Insurance usually blunts socially constructive incentives, but such insurance is nevertheless not generally barred. Risk aversion is apparently a competing, if private, good. Thus, we discourage sucli things as excessively fast driving and environmental pollution

(perhaps without making additional requests). Apparently, there is much to be understood about credible threats.

85 The suggestion is that Ybarra-like liability rarely extends to cases involving unconnected individuals because of the problem associated with such threats. More simply, legal systems may prefer broad, de facto group liability over refined Ybarra-style liability because an apparent advantage of the latter-its ability to provide compensation to victims-is the source of concern about false claims.

A related possibility is that the potential for threats creates a chilling, or activity-level, problein of the kind discussed but perhaps underestimated in Part I.A. It should be noted, however, that our civil liability systein presents many opportunities for similar liability and threats; although these costs inay in fact deter economic activity, they have not done so in a dranatic way, and they have not caused inportant changes in the rules theinselves.

86 Put differently, if Ybarra were extended to the case in which the harm done in the operating room were intentionally inflicted (but it was impossible to know by whoin), insurance would still likely cover the group liability thus imposed. To make the overextraction rule work we would need a rule barring insurance (or indennification or other contractual alternatives) for liability arising out of an overextraction scheme.

The noninsurability of virtually all criminal liability (even where there was no intent to cause injury) is itself noteworthy. Perhaps we are willing to see deterrence (as championed by tort law) dulled because of the offsetting utility of risk reduction, but we are unwilling to let retribution (the stuff of criminal law) be blunted because something more than risk and utility is at stake. It is also possible that once insurance institutions arose, criminal penalties came to be relied on as an important source of deterrence precisely because a clear line could be drawn between remedies that could and could not be spread and avoided. 
with a combination of criminal penalties and potential tort liability. The latter deterrence mechanism is blunted by the availability-or in the case of driving the requirement-of insurance coverage, although we may count on insurers to supply their own incentives to promote safe deportment. The criminal penalties, however, represent uninsurable risks. Intentional torts are sometimes also said to be uninsurable, ${ }^{87}$ but it is really only the intent to cause injury that interferes with imsurability; a great deal of insurable tort liability arises out of intentional wrongdoing (such as speeding). Group liabihty of the Ybarra kind, arising out of mjuries sustained in operating rooins or elevators or elsewhere, is also imsurable under present contractual practices and legal rules. This insurability weakens, but does not ruin, the information-forcing element of modest group hability, and we are apparently willing to tolerate reduced deterrence incentives in exchange for the private gains from risk spreading.

In terms of the comparison between moderate and overextractive group liability, the relative evolutionary success of moderate group liability (despite certain advantages of overextraction) can be explained with reference to the fact that only overextraction is incapable of tolerating insurance. Elevator passengers and factories along a (polluted) river would need to be barred from insuring against overextraction, and we do not generally bar insurance except where there is proof of serious wrongdoing (by the wouldbe insured) or immediate danger of moral hazard. We may be unwilling to impose penalties that are uninsurable when liability is based not only on something less than the criminal law standard, but also when liability is based on mere fortuity. Put differently, the risk imposed by the overextraction rule on innocent players is unacceptably great-especially or precisely because it cannot be reduced through imsurance. A sclieme that will not work if insurance is permitted may simply be unacceptable-unless its burdens fall only on those who are found guilty beyond a reasonable doubt or who intentionally do harm.

87 Robert E. Keeton \& Alan I. Widiss, Insurance Law \$ 5.4(d)(1), at 518-19 (1988) (stating that covered losses are those that are "accidental" not intentional). 


\section{E. Individual Responsibility Revisited}

I have already suggested that even (nonoverextractive) modest group liability is more likely where businesses rather than individuals are concerned. It is easy to grow accustomed to liability for environmental injuries even where there is no evidence that the particular defendant behaved negligently or caused the injury in question. In contrast, if personal property disappears from a law school hibrary, it is almost impossible to imagine that all who used the hbrary during the hours in which the wrongdoing occurred would be required to compensate the victim. There are at least three distinct ways of explaining this difference. First, as suggested earlier, ${ }^{88}$ lawmakers (and commentators) may discount the hidden costs that fall on businesses while identifying strongly with the burdens imposed on individual defendants. Second, individual-but not corporate or enterprise-liability may be associated with a moral taint, especially where the wrongdoing is intentional, and the law inay decline to stigmatize individuals where the identity of the wrongdoers is uncertain. Third, there may be no liability where the gain from satisfying risk averse preferences is likely to exceed any gain from an inexact deterrence scheme. ${ }^{89}$ At least two of these explanations suggest some hesitation to use group liabilityincluding vicarious liability and products liability-where enterprises are concerned.

\section{CONCLUSION}

The insurability of some group liability-but not of overextractive liability-is an important means of understanding the absence of overextraction and, more practically, the limits of Ybarra. But I have not developed the overextraction idea simply to offer solutions to the puzzle of its nonexistence. When a teacher reacts to juvenile misbehavior from an unknown source by penalizing the entire class with a missed recess, I do think the teacher is missing the superior alternative of adding to the threat of group liability a promise that if the wrongdoer confesses convincingly the wrong-

88 See supra Part III.A.

89 For instance, students and faculty who use a library may escape liability for missing items in the same way that the stockholders of a corporation enjoy limited liability. 
doer alone will miss half the recess period..$^{90}$ That the overextraction idea could easily be used in this and in other circumstancesbut is not-is itself something of a puzzle. It may well be that there is a failure of imagination or that it is difficult to innovate when it comes to the infliction of penalties.91 Alternatively, it may be that in classrooins, armies, occupied territories, prisons, and other settings where activity-level effects are least worrisome, it is also the case that shared goals or other bonds among members of the target group overpower the incentive to confess offered by any overextraction rule.

In the larger world of law, the overextraction idea may be most promising in dealing with polluters. In the case of a polluted waterway, for example, the key ingredients of successful overextraction may be present: uncertainty as to the wrongdoer's identity; nominal activity-level effects; modest judgment-proof probleins; and a target group with members that do not rally to one another's causes, that can self-insure, and that often elicit little political syinpathy.

The greater part of this Article has concentrated on the puzzles associated with the overextraction idea. An examination of a rule not taken can sometimes illuminate the tools we do use and the

90 In order for this strategy to deter future wrongdoing, the wrongdoer must prefer the half recess to the pleasure associated with the wrongdoing. Note that the absence of anonymity may be useful here if the wrongdoer's peers regard the wrongdoer as courageous and loyal when his confession restores to the class their recess period. But if peer pressure runs in the other direction, the teacher could offer the confessor a penalty comparable to the partially missed recess, but one that preserves anonymity. Finally, the example assumes that a convincing confession is possible. Thus, if the teacher finds an illicit note, confession might require the complementary piece of paper from which the note paper was torn.

91 As a legal matter, innovative penalties can be attacked as cruel and unusual. It is revealing, perhaps, that "unusual" is regarded as a bad thing when it comes to punishments. As an evolutionary matter, I think it safe to say that there is less willingness to think about innovative penalties (especially when imposed by the state on politically unprotected parties) than novel forms of reward. Of course, to the extent that wrongdoers may be judgment-proof, there is less room to innovate in the case of penalties than there is with rewards, where innovation often comes in the form of new opportunities for monetary reward. Still, the disinclination to innovate where penalties are concerned is noteworthy because there is also a general inclination to think that the penalties currently meted out generate enormous social costs, do little in the way of rehabilitation, and can be quite horrible and offensive in practice. 
values behind these choices. ${ }^{92}$ In this case, an analysis of the problems associated with overextraction serves to explain the scope of modest group liability (of the Ybarra kind). At the same time, there is the remote possibility that if the cost of undetected wrongful behavior grows, so that de facto communal liability increases, the alternative of overextraction will in some circumstances become more appealing. The greatest obstacle to such experimentation would appear to be the requirement that we change our expectations about risk bearing and our rules governing those risks that can be shared through insurance schemes. If these or other obstacles discussed in this Article are too formidable, then the point of this thought experiment will have been to understand better the limited role of explicit group responsibility.

92 In some sense the real subject of this project is "Rules not Taken." See also Saul Levmore, The Case for Retroactive Taxation, 22 J. Legal Stud. 265 (1993); Saul Levmore, Obligation or Restitution for Best Efforts, 67 S. Cal. L. Rev. 1411 (1994). A theme common to these projects, and to several forthcoming papers as well, is that by exploring the paths not taken, we can learn a good deal about the legal rules we know. 